\title{
Memoria y revuelta en poetas mujeres mapuche: intimidad/lazo social $\|^{1}$
}

\section{Memory and Revolt in Poetry by Mapuche Women: Intimacy/Social Bond II}

\author{
Gilda Luongo \\ Universidad de Chile \\ gildaluongo@gmail.com
}

\section{Resumen}

El presente artículo expone una trama indagativa que se sitúa en los cruces de poesía escrita por mujeres mapuche, memoria y diferencia sexual. Dos son las figuras centrales que explora la interpretación textual: pérdida del territorio/de la lengua y la lucha en el nombrede1@s caíd@s/en el nombre propio.La labor heurística se sostiene en un armado teórico-crítico múltiple: teoría crítica feminista (Butler, Braidotti, Kristeva, Anzaldúa), filosofía (Ricoeur, Blanchot) y crítica literaria (Blanchot, Genovese). El corpus seleccionado de las poetas mapuche proviene de una tríada textual que ha permitido leerlas de manera conjunta: Hilando en la memoria (2006 y 2009) de Soledad Falabella, Alison Ramay, Graciela Huinao, Roxana Miranda Rupailaf; y Kümedungun/Kümewirin de Maribel Mora Curriao y Fernanda Moraga publicada el año 2010.

Palabras clave: Poesía de Mujeres Mapuche, Memoria, Crítica feminista.

\section{Abstract}

The following article exposes an indagative narrative located in the cross between poetry by Mapuche women, memory and sexual difference. There are two central figures explored by the textual interpretation: "the loss of land/of language" and "the struggle in the name of the fallen/in one's own name". This heuristic work is based on a multiple-sided theoretical-critical framework: feminist critical theory (Butler, Braidotti, Kristeva, Anzaldua), philosophy (Ricoeur, Blanchot) and literary criticism (Genovese, Blanchot). The selected corpus for the analysis is drawn from three major anthologies by Mapuche women: Hilando en la memoria, edited by Soledad Falabella, Allison Ramay, Graciela Huinao and Roxana Miranda Rupailaf (2006, 2009); and Kümedungun/Kümewirin edited by Maribel Mora Curriao and Fernanda Moraga (2010).

Keywords: Keywords: Poetry by Mapuche Women, Memory, Feminist Critique.

1 Este artículo se inscribe en el proyecto CONICYT/FONDECYT/REGULAR/N ${ }^{\circ} 1110083$ "Memoria y escritura poética de mujeres en el Cono Sur de América, 1972-2010", de la Facultad de Filosofía y Humanidades de la Universidad de Chile. En esta instancia de indagación académica me desempeño como Co-investigadora. 
sólo la poesía preserva la fuerza del no-olvido refugiado en la aflicción.

Paul Ricoeur (641)

La memoria como el cuerpo está viva y duele y sangra.

Maribel Mora Curriao, (Hilando, 177)

El olvido de reserva [...] es tan fuerte como el olvido de destrucción.

Paul Ricoeur (646)

\section{En tono de exordio: una allegada²}

Llegar a la poesía de mujeres mapuche como quien entra a un territorio que pide una pisada tenue, de pie pelado. No porque haya que tener cuidado, ni porque incite un despliegue epistémico heteróclito. Esta demanda de lo delicado, de lo delgado o débil en el paso indagativo tiene que ver -desde esta sujeto y su lenguaje crítico-con el territorio denso-pleno en diferencias-diferentes marcadas a fuego por la historia, la sociedad chilena y la cultura mestiza. Esta afirmación brota del posicionamiento ético-estético y político que enmarca mi indagación crítica ${ }^{3}$. Producción de lugar, lugar de producción, por ello, urge esclarecer este intento-crítica ético-política, cultural a la vez que literaria, de modo más fino. Para ello me nombro allegada a estas creaciones poéticas. Lo hago a partir de lo que me sugiere la lectura de Paul Ricoeur (170-172). Señala el filósofo que para disolver la molesta dicotomía entre memoria colectiva y memoria individual, habría que entrometer en medio, una tercera noción, la del allegado. Interpreto esta figura muy próxima a la labor que hacemos en estos campos de indagación relativos a la memoria en cruce con otros ámbitos de la vida cultural: creación poética de mujeres en el Cono Sur de América Latina. La allegada aparece como figura de proximidad, de cercanía; en cierto sentido de complicidad,

2 Este apartado abre el presente texto como reiteración del tono escritural -ético-estético-político- perseguido en una primera aproximación a la poesía de mujeres mapuche en un artículo ya publicado. Ambos se hallan concebidos en la forma de un plegamiento. Ver: Luongo, Gilda, "Memoria y revuelta en poetas mujeres mapuche: intimidad/ lazo social I" en Aisthesis No 51 (2012): 185-201.

3 Debo señalar que este posicionamiento crítico feminista se hermana con la línea que nos ofrece generosa y provocadoramente la filósofa feminista Rosi Braidotti cuando elabora sus disquisiciones ético-políticas respecto del lugar que cada una de nosotras asume cuando elaboramos nuestras ideaciones. La pensadora nos compele a imaginar, a crear figuraciones que sean capaces de dar cuenta de nuestros sitios móviles y comprometidos. Crítica feminista, sigo sus provocaciones y tomo el desafío que nos arroja este modo de hacer escritura. Braidotti señala: "El feminismo sostiene que la evocación es un modo de superar las huellas de la violencia, aplicada con regularidad por regímenes opresores en todo el mundo. Es un acto de creación que moviliza no sólo la experiencia sino la imaginación" (Braidotti, 2009, 232, cursivas añadidas). 
pero también aparece a modo de figura de distancia como espacio (im)posible en tanto puede ser un corte en las filiaciones o relaciones familiares consanguíneas o en las sociales y su orden de grandeza. Elijo en este inicio exponer el juego de aproximación y distanciamiento que emprende esta escritura, un movimiento pleno de modalidades surge de esta forma de situarme frente a la labor memoriosa de las otras y de cada una, esfuerzo que ocupa un territorio indagativo desde el cual pueda emerger una relación dinámica y frágil entre otras. Así, próxima privilegiada, asumo una pertenencia móvil, nómade, en esta tarea crítica acerca de la memoria poética desplegada en la creación singularizada de mujeres mapuche. La allegada cuenta como vínculo cercano/ distante, cuenta para el "nosotras" comunitario y cuenta para el sí mismo, individual. Me importan las variaciones de ese juego de cercanía/ distanciamiento que mi escritura crítica pueda incubar. Tan lejos tan cerca, sería un modo condensado de decirlo.

Selecciono otro elemento convocante de la hermenéutica crítica de Ricoeur relativa al sitio de "allegada" a la memoria. Este se halla vinculado a la noción de 'atestación' que el filósofo francés propone para esclarecer el vínculo surgido a partir de la aprobación mutua, del compartir. Cada quien puede atestar que habla, actúa, narra, por ende puede imputarse a sí misma/o la responsabilidad de su acción ${ }^{4}(40)$. La allegada, en la cercana distancia puede dar cuenta de la otra en la medida que le importan su nacimiento y su muerte. Celebrar la natalidad y el nombre de las poetas mapuche implica aprobar su existencia; del mismo modo, ellas pueden celebrar la mía en este registro que comparte la creación de mujeres en toda su compleja red de sentidos. Tal vez sería interesante imaginar que puedan no aprobar mis acciones, sin embargo, imagino que sí pueden afirmar que exista cercana-distante en este trabajo con (de) la memoria poética. Por otro lado, dar cuenta de la muerte que subyace en sus recorridos, en sus experiencias vitales doblemente singularizadas -como mapuche y mujeres-, resulta exponer el envés de la vida. Podemos de este

4 En una nota al pie el autor precisa esta idea contenida en su texto Sí mismo como otro en el que declara trabajar esto de las capacidades o poderes de base: poder hablar, actuar, narrar, considerarse responsable de los propios actos, lo que denomina como "el hombre capaz". Genericidad que bien podríamos intervenir desde la generidad: "la mujer capaz". En consecuencia, le interesará dar cuenta de que la única manera de acceder al pasado es la memoria porque no hay otro recurso disponible para ello. Cuestión fundamental a la hora de detectar, por ejemplo, el trabajo con la memoria en la poesía. Planteo posible preguntas, a partir de esta disquisición: ¿cuán constitutiva es la memoria a la producción poética de mujeres en América Latina? Si la cuestión de género y de la teoría feminista ponen en la escena las experiencias de las mujeres en su constitución de sujeto individual y colectivo, ¿no resulta inevitable el trabajo con la memoria dado que el pasado constituye una modalidad temporal fundamental para los procesos de re-creación genealógica del mundo desde la afección-acción de las sujetos femeninas en este continente; lo que implica, asimismo, desplegar en esta acción, -siguiendo a Ricoeur en su nota al pie-, las capacidades y responsabilidades de sus propios actos? Aquí, aparece claramente la cuestión ético-política que implica la producción de memoria de las mujeres en todos los ámbitos, y en particular, en este de las escrituras de poetas mapuche. Por otra parte, Ricoeur señala que la memoria estaría vinculada a una ambición, una pretensión: ser fiel al pasado. De este modo en la emergencia del olvido, el autor propone tratar a este no como una patología de la memoria, sino como "el reverso de sombra de la región ilustrada de la memoria, que nos une a lo que ocurrió antes de que hiciésemos memoria de ello". Nuevamente pienso en esas sombras que constituyen nuestro pasado en tanto mujeres que hemos dado la batalla por constituirnos como sujetos individuales e históricos-políticos-culturales. ¿Cuánto de esas sombras y cuáles pueden ocurrir como un envés en la producción de memoria en las escrituras poéticas? 
modo completar el círculo o la espiral que abre el trabajo memorioso con/en la poesía de estas diversas creadoras de la palabra viva, sea mapuche o híbrida en su (des)pliegue de sentidos.

\section{Deslindes}

Una trama teórico-crítica triple sostiene esta indagación, una trilogía: escrituras poéticas, memoria y diferencia sexual-étnica. Una ética-estética-política posible. Esta triangulación levanta "otro" modo de leer poesía (Genovese 9-11), uno contaminado/ contagiado con esferas múltiples, abanico desprendido desde los ricos conceptos implicados en ella. Importa el avistamiento de anclajes, puntos de apoyo para leer estas producciones en lenguaje poético. En este despliegue, me aferro a una punta singular: la acción de fondear. Reconocer el fondo del agua en estos roces: memoria-política/ escrituras poéticas/diferencia sexual-étnica; registrar si hay 'géneros prohibidos o de contrabando'; contrabandear en esta labor; examinar con cuidado lo que hay, lo que surge como conocimiento múltiple, ensuciado por vértices innombrados. Investigar y leer escrituras poéticas en los cruces implicados permite articular reflexiones dilatadas, espaciosas entre intersticios. Ello implica ir más allá de los límites teóricos impuestos por criterios estrictamente literarios. Este fondeo hace emerger los excesos de la memoria/de la imaginación poética/en un recorte ético-estético-político.

Con Ricoeur aludo a la imagen-recuerdo y a la memoria feliz (106), aquella que no puede estar lejos de la justicia. Me importa el modo en que lo estético aparece en este lenguaje y se imbrica con lo ético-político a partir de la noción de diferencia sexual e identidades múltiples. La apertura en este exceso arma pliegues de memoria, contra-memoria, zigzagueante, desordenada, libre de temor (Braidotti 2009). Imbricaciones a partir de imágenes, ausencias que se hacen presencia gracias al alejamiento: sólo aparece lo que se ha entregado a la imagen (Blanchot 243-252). Resurgimiento de referentes que exponen el lazo social mixturado entre imaginarios mapuche de hoy, los que pulsan renacidos, junto a otros ecos antiguos. Reverberaciones, latidos urgentes.

La memoria feliz posibilitaría en la escritura poética lo ostensible, aquello que nos conmueve por lo que hace reaparecer, lo que vuelve, revuelve, nos revuelve porque 'parecía' des-aparecido. Desdicha, penalidad, dolor en las escrituras poéticas, impulso/ deseo que reinscribe la labor memoriosa desde la escritura, aun cuando sea sólo una fantasmática. Pienso en lo que Ricoeur llama "olvido de reserva" (548) como aquella zona de lo que estaba allí, que parecía haberse esfumado, parecía no estar más, pero que con porfía secreta esperaba aparecer. Tal vez las escrituras poéticas en cruce con género y diferencia étnica-mapuche posibilitan la difícil emergencia de aquello que está más atrás, innombrado aún y se desata como flujo en la conexión memoriosa/ imaginaria. Esta vertiente entra en juego con lo que el mismo filósofo francés denomina "olvido por destrucción de huellas" (533-535). Si hubo destrucción, es posible que el 
latido del 'olvido de reserva' recree esas huellas otra vez y así de modo interminable. Por ello, cada vez que las y los lectores entramos en complicidad memoriosa con estas creaciones, vuelve a latir ese pulso generoso, que pone rostro a 1@s invisibilizad@s, a 1@s expoliada@s y junto con ello dibuja los rostros disímiles de quienes luchan hoy y nos hacen partícipes de su existencia.

Durante los años 2011-2012, me he dedicado con obsesión a estudiar la producción de las poetas mapuche considerada en tres antologías que abren un buen abanico respecto de estas singulares construcciones de lo poético. He señalado en el artículo ya publicado (Luongo 190-191) la importancia que tiene una de ellas por el rigor y la amplitud con los que fue diseñada: Kümedungun/Kümewirin. Antología poética de mujeres mapuche (siglo XX-XXI) publicada por Maribel Mora Curriao y Fernanda Moraga (2010). Este texto se ofrece ancho para la crítica rigurosa. Asimismo, las antologías Hilando en la memoria. Siete mujeres mapuche (2006) de Soledad Falabella, Allison Ramay and Graciela Huinao junto con Hilando en la memoria. Epu rupa. Catorce mujeres mapuche (2009) de Soledad Falabella, Graciela Huinao y Roxana Miranda Rupailaf ofrecen un crisol que hace posible leerlas de conjunto. A partir de estos textos he seleccionado algo más de ciento treinta poemas referidos a la trama de lectura que me ha ocupado en estos dos años: el examen de cuatro figuras detectadas desde la trilogía conceptual que mueve esta indagación ${ }^{5}$. Con la finalidad de que este ejercicio de lectura crítica intenso se plasme en publicaciones, he tomado en este ejercicio heurístico una muestra acotada de ese corpus tanto más rico cuanto más vasto.

\section{Figuras memoriosas de la revuelta/lazo social}

Dos son las zonas/figuras escogidas en la poesía de mujeres mapuche en las cuales este escrito indaga de manera específica: "pérdida del territorio/ de la lengua" y "la lucha en el nombre de1@s caíd@s/ en el nombre propio". Ambas desatan hebras, hilos que arman una trama de habla poético-política situada en medio de una comunidad y su bregar por existir como tal. Una figura remite a la otra de modo ineluctable. Surge de este modo un mapa cuyas entradas se abren en abanico: desgarros coloniales, exilios citadinos, la geografía/ tierra; el mapa-mapu habitada/deshabitada, robada, usurpada, los sueños como huellas de recuperación de territorios; una simbólica que arranca múltiple en este llamado territorial: deseos, ritos, una lengua/cultura atravesada por migraciones cuyo latido colonial estalla múltiple (Antileo 193-204); la traducción inevitable; localización, datación; las palabras perdidas/anheladas en mapudungun; el regreso de las palabras, re-aprender la lengua: territorio esperado; la comunidad

5 En el escrito de mi autoría publicado en Aisthesis (2012), llevé a cabo el examen de otras dos figuras a las que nombré: Imágenes de infancia e Imágenes del cuerpo/entorno. 
reinventada con porfía, el lazo social emancipatorio, el colectivo re-inventado en la lengua/tierra: el hermano, la hermana, el abuelo/la abuela, huellas de escritura, huellas de oralidad; la palabra poética memoriosa descifradora de huellas mudas, (Ricoeur 227), instauradoras de discursividad (Foucault 101-104). Una geopolítica: dimensiones y heterogeneidad geográfica vastas, reconstrucciones del pasado arquitectónico, violentas demoliciones culturales: construir, destruir, reconstruir. Documento/monumento, archivos del despojo (Nahuelpán 123), el winkün, acto de vejamen, usurpación, desgarro (Nahuelpán 151); lupa, microscopio, telescopio; la historia cultural, política y literaria como búsqueda de testimonios e indicios (Bengoa 2008, Bello 2004, Antileo 2012, Mora Curriao 2012); huellas múltiples. Así emerge la poesía como zona indicial. La historia anhela la verdad dice Ricoeur, la memoria, la fidelidad. El gesto poético-ético-político pone rostro a todo aquello condensado como recuerdo-imagen. Pienso en la afirmación de Butler cuando dice:

\footnotetext{
Lo que está privado de rostro o cuyo rostro se nos presenta como el símbolo del mal, nos autoriza a volvernos insensibles ante las vidas que hemos eliminado y cuyo duelo resulta indefinidamente postergado. Ciertos rostros deben ser admitidos en la vida pública, deben ser vistos y escuchados para poder captar el valor de la vida, de toda vida. Así no es que el duelo sea la meta de la política, pero sin esa capacidad para el duelo perdemos ese sentido más profundo de la vida que necesitamos para oponernos a la violencia (21).
}

\section{Pérdida del territorio/de la lengua}

El poema "Pewküleayu” (Hilando 2006, 43) de María Isabel Lara Millapán está escrito en clave del tiempo pasado y la pérdida que este abre, a la manera de una herida. El primer verso pareciera expandir el poema-relato donándose a otro, un semejante: "Hubo que partir un día hermano". El bosque, el vapor de la tierra, la mañana de sol luego de la lluvia y las lagunas, parecen lejanos desde el momento en que hubo que partir. Dejar que no implica olvidar. Por el contrario, el despojo del corazón por la partida desde este lugar propio, el territorio, se convierte en sueño y emerge en este a manera de cabalgadura: el deber de memoria necesitará ser dicho poéticamente. La palabra "huella" podría estar asociada a aquello que Ricoeur denomina "huellas mudas". Esas que laten con porfía antes de ser desveladas. Los ancianos y sus sentimientos están allí como signo, como imagen en la rogativa. Una herencia, una genealogía, cierra el poema al asentar el sujeto en plural, lugar que convoca el deber de memoria: "Los encargados somos de llevar estos sueños".

La misma poeta, Lara Millapán en el texto "Identidad" (Hilando 2006, 51) ofrece a esta escritura crítica el lugar del reconocimiento vinculado a esa memoria. Olvidar, irse los sueños, aquellos que en continuidad con el anterior poema parecieran resguardar la memoria. Dice: 
“¿a dónde quedan los hijos de la tierra?

¿a quién enseñamos el silencio de nuestros bosques?”

Como pregunta retórica instala el vacío comunitario, pero su envés levanta a esas figuras humanas que al aparecer borran las interrogantes. Unos versos más abajo, la respuesta (im)posible:

"Para volver hermano

Para volver...

Porque aquí está nuestra tierra."

El adverbio de lugar "aqui" hace ostensible, como imagen del sitio, aquello que parecía perdido: ¡es allí! Es el mapa. Si el reconocimiento nos constituye existentes, esta palabra poética inaugura otra vez ese espacio y los sueños imbricados con el "hermano". Sigo a Butler cuando señala que el despojo nos revela algo de lo que somos: "algo que dibuja los lazos que nos ligan a otro, que nos enseña que estos lazos constituyen lo que somos, los lazos o nudos que nos componen." (48). No es posible aparecer si no es con otros/otras en el territorio recuperado en la memoria/imaginación. Cuán fácil resulta eliminar a otros, dice Butler (20) señalando una reflexión necesaria relativa al modo en que esta "identidad" de hermanos mapuche en este poema hace ostensible su fragilidad, su vulnerabilidad en la pérdida territorio/ lengua.

Adriana Paredes Pinda, en su poderoso texto poético "PARIAS” (Hilando 2006, 85-94) borda una palabra poética teñida por el cuerpo y la genealogía de mujeres y hombres del pueblo mapuche (Luongo 2012). Si bien la materialidad del cuerpo asoma central en el poema como una sintaxis-cabalgata desbocada, la "lengua árbol" mapudungun, encabritada, emerge para señalar el territorio la cultura ancestral desplegando instrumentos musicales, danza que acompaña a este verbo-cuerpo desatado, híbrido. En esta coreografía la lengua no está perdida, aparece anclada a la "lengua-clítoris", a la lengua-goce en la que pareciera caber también la mixtura, la hibridación. En este texto poético la frontera parece disolverse. El neplantismo, la tierra de en medio, emerge poderoso, vital, afirmativo. Si Neplanta es una frontera, y como tal lugar incubador de memoria (Sierra 111), puede llegar a ser un estado liminal que posibilite enhebrar lo político, lo espiritual y lo artístico. El trabajo memorioso surgirá del "cenote", una especie de estanque, de lugar que acoge, acopia y contiene memorias difíciles de evocar según lo elabora Gloria Anzaldúa (Sierra 113). No obstante la dificultad para realizar dicha labor, este poema bello y potente logra su cometido memorioso y culmina con dos versos conmovedores que asientan el tiempo pasado, pero eterno en su duración, que no acaba ni acabará: un territorio afectivo-espiritual ligado a la cosmovisión mapuche inacabable: 
En "De por qué escribo" (Kümedungun 413), la misma poeta Adriana Paredes Pinda, asienta el lugar ladrón de la lengua castellana, del español. Esta es la razón por la cual escribe: el robo legalizado de la lengua mapudungun por la lengua castellana. La escritura poética contiene la pérdida. Entonces la creación poética de esta autora no puede ser un don. Es un asalto. Es una violencia cometida sobre quien está bajo estado hipnótico. Esta "lengua meretriz", la ha tomado sin su autorización. Por ende, le ha robado su territorio, el mapuzungun, y la poeta no logra zafarse de esta toma, de esta posesión indeseada. Enuncia el lugar poético como un estado quemante, una hoguera, dice: "esta weñefe, este pensar weñefe de mí..." La culpa cristiana se trenza en esta labor: "y yo "pecadora", pobre de mí, me he enamorado de la lengua castellana meretriz." Si no escribe en mapudungun, la lengua usurpada, está montada a contrapelo en la lengua meretriz, luego se empeñará en devolver a ésta el asalto y lo hará violentando su sintaxis y su semántica ladronas, violentándose a sí misma. Este es un signo en su poética, uno que refiere a la pérdida de la lengua originaria por violación y asalto. Leo la muerte como un llamado desde la escritura. La muerte para vivir de otro modo en ella. Uno que no permite respiro, uno que es asfixia, combate, desgarro.

Alejandra Llanquipichún, en su poema "Lo que no es poesía” (Hilando 2009, 18) asienta una voz que narra la travesía del despojo de tierras, padecimiento de los ancestros. La memoria del robo, el engaño, la estafa se sitúa en aquellas zonas de lo que "no es poesía". La concepción poética idealizada pareciera subsistir en esta afirmación. Luego, ¿qué es la poesía en esta voz? Si la expoliación puede ser evocada en el lenguaje poético, entonces la poesía, esta labor poética, se erige como un espacio que hace posible una justicia. La voz poética se apropia de este lenguaje para romper el silencio y la violenta desposesión.

Por otra parte, en el poema "Primera lección" (Hilando 2009, 21), la misma poeta Llanquipichún, da voz al sujeto hablante que conoce acerca del estado de desposesión del espacio propio, del lugar de la acogida y del bienestar, por ello se hace voz de "lección". El exilio experimentado abre a la experiencia del regreso posible al lugar natal. La voz se convierte en enseñante, en una guía para encontrar el camino de vuelta a casa, la huella para llegar al "tiempo lejano". Volver al origen, a la tierra, a los maderos, a las plantas, al agua fluyente del río, al nombre nuevo, al abuelo, al silencio, a la "lengua de los soles". Allí se encontrarán: aprendiz y enseñante en la tierra múltiple anclada en la lengua:

"Quiero que sepas que tu felicidad va a estar ahí donde se

hizo tu vida,

[...],

cerca del sol

cerca de la tierra". 
En el poema largo, "El último enemigo", de Graciela Huinao (Hilando 2009, 125-9) la voz poética enuncia, en tono testimonial, aquello que le dejaron sus muertos. La muerte viva, otra vez, como si la poesía, lugar de la muerte incubara otra vida. Esta voz se nombra como heredera de "sus misterios y sus porfías", por lo tanto resulta partícipe del colectivo ancestral. Su enunciación luego se transforma. Se convierte en una especie de "ajuste de cuentas" cuando después de recorrer el camino por la pérdida se vuelca en el "Hoy". Una especie de ceremonial de sinceridad ocurre en su discursividad dialógica consigo misma, en su ejercicio memorioso. El tono, sin embargo, no es grandilocuente. Es frágil y despierta en la voz el reconocimiento de la labor de enunciación en este poema. Sin embargo, esta tarea aparece signada como doble en su impulso: ofrece una vía posible de luz, a la vez que pareciera envolver a la sujeto hablante creadora en una voluta de cristal fría que tiende a domeñarla. Con todo, la salva de permanecer en una memoria museográfica, petrificada, vuelta pieza inánime. La memoria dibujada en lenguaje poético nunca será parte de la vitrina de museo. Por eso, dos gestos discursivos, simuladores de una arena pública, sostienen su ética-poética ambigua: la promesa y la declaración. La primera pareciera ceñirse al deber de memoria, la segunda, abriga a la memoria desdichada, porque en su descarnada afirmación desvanece el impulso justiciero. En la primera señala:

"Me prometo:

'Antes que los años estrangulen mis recuerdos

o la madre naturaleza me acune en el regazo del olvido

con esta hebra poética me obligo a zurcir la tierra

que me fue legada con muchas heridas"' (126)

En el segundo gesto dice:

\section{"Declaro:}

'En la última invasión escondí las armas.

Una nueva bandera abracé en mi camino

la vanidad pacificó

el último bastión rebelde que poseía."' (127)

El lenguaje poético urde ambas vías. Su tensión pone en vilo a la voz que necesita escoger. En el final del poema este conflicto pareciera ceder porque la presencia de "el último enemigo" vuelve a encender "la milenaria vertiente". El agua es aquí el flujo no sólo de la vida de la cultura mapuche, de su alegría, sino también el flujo de la creación poética, de esta voz que nos arroja las palabras a manera de re encantamiento agónico. Entonces, la trinchera será la vertiente que aunque "huella de agua petrificada" logra que la voz poética diga "dejaré la vida" por ella. La "promesa" cobra fuerza y vence a la "declaración”, tal vez porque la primera no necesita estrado ni ministerio. Se promete sólo desde el corazón; se declara, por el contrario, en un tribunal público.

La misma poeta Graciela Huinao, en el escrito "Simulacro de autobiografía" (Kümedungun 181) refiere, en continuidad con el tono del poema anterior, su conexión 
amante con el sur perdido, abandonado y recobrado como silueta difusa en la escritura. Ese punto cardinal reverberante y memorioso se perpetúa en su poesía. El tránsito de su migración hacia los márgenes de Santiago, en los setenta, dibuja la condena del hambre. La sujeto enunciante relata su nacimiento alimentado por el sur en un hogar obrero mecido por el canto del padre en mapudungun. La escuela, territorio hostil impuesto en ese mismo sur, desconoce su cabello oscuro y la ubica en los últimos puestos. Tempranamente, padre y madre dejan caer la muerte en su desolación poética. La memoria territorial, sureña en lo amoroso, se expande para invadir el espacio citadino habitado como ajeno. De ese modo surge el sostén ambiguo y frágil de la escritura poética.

Roxana Miranda Rupailaf, en un poema sin nombre (Kümedungun 365) crea una voz poética teñida de rojo por el dolor de las masacres. Esta voz profética, a la manera de Casandra, no puede sino escribir acerca de esta pérdida. Las muertes la alcanzan no sólo porque ella es la profetiza, sino porque este lenguaje se erige como el especial lugar del duelo al constatar la profecía cumplida:

Se cumple la profecía

y derramo la tinta por los ojos.

La memoria de la profecía es la herida de la escritura-sangre. Su derrame se condensa frágil en los murmullos de las plegarias. Se cuaja en ese dolor colectivo que esta voz se encargará de repetir al infinito. La veladora de la escritura escribe "con velas en los ojos". La escritura derramada pareciera ser infinita, interminable. No hay asomo de memoria feliz que cubra la imagen recobrada. La escritura poética puede ser el pulso del desgarro perpetuo.

Liliana Ancalao, en su bello poema largo "Las mujeres y el viento" (Kümedungun 137) pone en escena la manifestación del viento en una comunidad habitada por mujeres que parecen no tener hombres. Una mujer profetiza, llamada en el poema "la griega", advierte el regreso del viento/hombre en la borra del café. Para la voz hablante, sin embargo, no es el hombre sino el viento quien siempre va a volver y el que cumple una labor múltiple entre ellas. El viento puede desparramarlo todo, borrarlo todo, volarlo todo y entonces:

se desafina la casa

la memoria se astilla (137)

La llegada impetuosa de esa energía volátil implica, asimismo, la espera de su partida. Sin embargo, nadie sabe cómo ni cuándo ocurrirá ésta. Y el recuerdo del viento persiste. La hablante rememora otro ventarrón narrado por su abuela: un malón que dejó sólo muertos, su sangre desparramada "y eso que los antiguos eran duros" (139). La voz hablante figura en el lago, del que sorbe un trago, esta imagen memoriosa del rojo sangre. Al volver al presente y al "aquî" de la enunciación, el viento ha hecho estragos: se escucha, como una pausa, el ruego de Ignacia Quintulaf para que su hijo perdido regrese. Luego, se vuelve amenaza hacia las mujeres: 


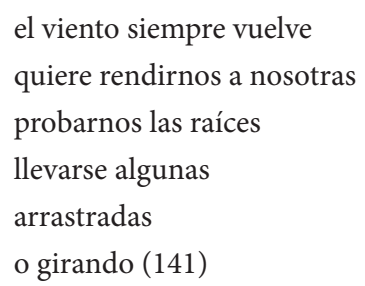

Pero como dice la griega adivina:

el viento amaina

y el planeta se pone transparente.

Luego, la imagen de un pequeño tallo y sus hojas alzándose del suelo aparece sutil. La voz hablante señala:

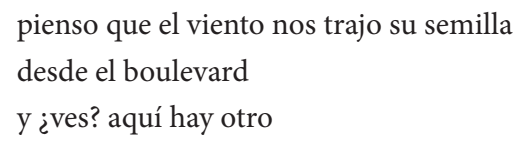

Entonces los olmos crecerán gracias a esa energía poderosa que encarna el viento, la que traslada la vida diminuta de un territorio a otro más lejano porque su poder es ilimitado y los hijos "claros" que vendrán serán como los olmos: llevados de un lugar a otro. Esta (des)esperanza mixturada pareciera potenciar y disminuir a la vida en sus cambios. El peso de esa energía ilimitada, incontrolable, es similar a las "arenas en las coyunturas" que impiden el flujo trashumante:

$$
\begin{aligned}
& \text { y no hay palabras } \\
& \text { quién sabe dónde } \\
& \text { las estará sembrando } \\
& \text { el viento" (142-143) }
\end{aligned}
$$

El poema abre el movimiento de una energía invisible, aquella sin embargo se hace presente a través de las materialidades y territorios que son afectados, transformados por ella. En su brío poderoso el viento puede hacer estragos, volverse enemigo, pero a la vez, puede sembrar la vida, una distinta. Tal vez una vida ajena y a pesar de que las palabras para nombrar esta transformación vital se pierdan, en algún lugar ese brío perpetuo se estará manifestando como una siembra múltiple.

\section{La lucha en el nombre de I@s caíd@s/en el nombre propio}

Enciendo un lugar, espacio, sitio en este escrito para que alumbre la palabra poética como arma que hace brillar, porque restaña, la intimidad y el lazo ancestral: la lanzapalabra, boleadora-palabra, kultrun-palabra; piuke-palabra, domo-lamngen palabra, 
weychafe-palabra, mapudungun-palabra: la espera en el nombre de los/las caídos/ caídas recientes-antiguos enredados en el nombre propio: re-encuentro de hermanos y hermanas en esta recobrada guerrilla poética memoriosa.

Liliana Ancalao nos dona el poema "Esperando a Inakayal" (Kümedungun 147) que escenifica el retorno del lonko. Interpreto este regreso desde la vitrinaprisión museográfica a la tierra en las manos de dos sujetos femeninos. Las mujeres lo esperan, los nombres de Fabiana y Silvia se unen al de Inakayal. Las dos mujeres se recortan como figuras impacientes, celestes y de espaldas a la luna. La imagenrecuerdo es el re-encuentro. La voz poética trae esta re-unión sagrada desde el "fondo azul", el trazo colorido espiritual que completa la mirada holística de la comunidad: el lazo se dibuja hermoso. El duelo se conforma estético-ético-político condensado en la imagen:

$$
\begin{aligned}
& \text { recorto sus figuras y las traigo } \\
& \text { desde antes y hasta el horizonte. }
\end{aligned}
$$

En el poema "Esta voz" (Kümedungun 145) Liliana Ancalao nombra la emisión, el origen y los derroteros del sonido de 'esta voz'. Elucubro que remite a la voz poética, a su genealogía antigua, diversa y a su intento fuerte/débil de poetizar. Con hermosas imágenes nos lleva a recorrer el camino de esta voz desde su nacimiento. No hay en ellas un límite de inicio o término, sólo hay apertura entre materialidades orgánicas e inorgánicas. Los nombres se multiplican. Puede ser una respiración:

$$
\begin{aligned}
& \text { Ella respira en la membrana } \\
& \text { de un tambor remojado en la garganta } \\
& \text { desde la piel de cueros costurados } \\
& \text { hasta la aguada de los teros } \\
& \text { lejos }
\end{aligned}
$$

Puede ser un cóndor suicida, desplegado en las alturas:

$$
\begin{aligned}
& \text { a veces } \\
& \text { cuando pienso las alturas } \\
& \text { soy un cóndor que se arroja contra el frío } \\
& \text { arrancándose las alas en el filo de los pinos }
\end{aligned}
$$

En "Esta voz" los volcanes se encienden en sus dedos y los potros truenan "torturados" en las venas. Esta lucha así nombrada resulta de una belleza esplendorosa en su fuerza y en su dolor. Voz que en su porfía puede llegar a ser ceniza en los labios y pretender ser cascada en el desierto. Ambas potencias materiales: el árbol/madera, deshecho, desfigurado por el fuego y el agua, elemento de la fertilidad humana, origen de la vida, porfiando en las sequedades y los páramos.

La agonía vital pareciera cerrar este poema hermoso desde el grito y el silencio, dos nombres en la lucha que bautizan para siempre a "Esta voz" múltiple en nombres: 
desde la sangre caer mi llanto

gritar

hasta el abismo del silencio.

Maribel Mora Curriao, en el poema “Berta Quintremán mira desde lejos el BíoBío” abre una voz poética que apela a Berta en la memoria. Ella es una de las ñañas mapuche-pehuenche que dieron una lucha ejemplar contra la empresa ENDESA España y el gobierno chileno, en la construcción de la hidroeléctrica Ralco, a fines de los ochenta hasta el año 2003 en territorio mapuche. Las hermanas Nicolasa y Berta, entre otras, batallarían sin tregua en defensa de sus tierras, de su cultura, de sus ancestros. Apelarían a los y las jóvenes para levantar el newen contra la usurpación europea en connivencia con la chilena. La imagen de Berta en el poema se perfila en medio del valle y de su casa, erguida, fuerte. Y la voz poética pareciera anticipar el desaliento:

Y lloraremos tu casa y tu valle

Por las noches y en silencio.

¿Qué mira desde lejos Berta? ¿Qué hay en esos ojos de ñaña antigua, sabia luchadora? No es sólo la tierra usurpada. El movimiento de la enunciación es pendular y dubitativo: abrir/cerrar, olvidar/recordar, morir/vivir, irse/quedarse. Este movimiento doble es desechado al final del poema, porque ninguna dicotomía alcanza a nombrar el indecible $(\sin )$ sentido de la experiencia de la pérdida, del exilio, de la lucha contra el capitalismo global y despiadado de Occidente.

María Teresa Panchillo en el poema “Calibre 2.568” (Hilando 2006, 81) abre otra memoria desdichada: la expoliación del pueblo mapuche durante la Dictadura Militar en Chile. El título del poema alude al Decreto Ley 2568 promulgado a comienzos del año 1979 en el que se dictaminaba: "a partir de la división de las tierras dejarán de considerarse tierras indígenas e indígenas a sus dueños" (Mora Curriao y Moraga 128). La voz del poema construye este dictamen como un disparo de una bala pesada, mortal, así su sonido y eyección se expanden. Este proyectil tiene como blanco la labor poética. Esta se convierte en el nido de la comunidad mapuche en lucha, en migración, en revuelta, en resistencia a la Ley winka:

Porque soy poesía -madre

Naciente

En la resistencia

Porque soy canción celeste del universo

Porque mis hijos se levantan

Enfurecidos y sonrientes

En las comunidades

Asumen la emigración

En las ciudades

Buscándome" ( 81) 
La poesía es una defensa, una trinchera, una zanja de tierra posible desde donde responder. Esta es feraz en su porfía de lenguaje, espacio-tiempo para la memoria. Por ello no hay posibilidad de derrota, en la poesía sólo hay permanencia en revuelta de lo femenino marcado como útero para la resistencia inagotable:

No acallarán las voces de mis hijas

Femeninas y maternales

Proclamándome

Desde el vientre del tiempo

Desde la prisión

Renaceré como fuego encendido

Bajaré de los volcanes

Armada de canciones y palabras nuevas

Porque en quinientos años

Nunca han podido

Dispararme en la boca. (82)

La poesía como boca, un orificio inhallable para el colonizador/dictador. Un hueco nutricio por el cual entran y salen las palabras que liberan, donde se hallen, a los hermanos y hermanas mapuche.

Hay un segundo poema en el que María Teresa Panchillo levanta esta vez, el nombre propio de "Lautaro" (Hilando 2006, 75). En él se escenifica su regreso condensado en seis versos. En su brevedad, el lenguaje dona el retorno del nombre marcado: "Lautaro de los tiempos". El tono poético de esta voz se hace sutil, liviano, hermoso en su simpleza, pero rotundo en la afirmación de la libertad. Así esta se vuelve herencia en cierne para la voz poética:

Retorna en media luna
Intacto y desafiante
Capullo de mi libertad.

Por su parte, Rayen Kuye en su poema breve sin nombre (Kümedungun 195) honra en imágenes a Lautaro. Su figura se alza entre otros nombres que son sus multiplicaciones: puma, cóndor, madre y así vestido con los atributos del ágil felino, del ave veloz majestuosa y de la sabia sujeto femenina nutricia que le dio la vida:

a lanzazos se abre paso

entre la caballería

del ejército español.

En este poema mínimo, la escena memoriosa construye el lugar de la lucha justiciera dispar entre el weychafe libertario que porta sólo una lanza y el invasor que se multiplica entre caballos y arcabuces. Sin embargo, los atributos que visten a Lautaro lo conforman con una fuerza invencible: su nombre propio y todos los nombres que en él perviven. 
Viviana Ayilef en su poema "Arte poética" (249) pareciera decirnos que la poesía es memoria. Afirma: "viene después" porque lo que hay "antes" son los compañeros, las miradas de los hijos, los viajes, sus historias "otras". Entonces, la palabra poética vendrá después, porque antes está la lluvia, el vivir migrando "entre lo propio más ajeno", en las ausencias, en los despojos. Así, la palabra poética llega "únicamente" para "calmarnos", como si arribara luego de una ardua lucha, después de una batalla por recuperar la vida: lo que hubo antes. Pareciera que ella, en su ancha plenitud fugaz, alimenta esta poesía agónica que se debate entre la vida/ muerte porque el "antes" resulta asido al duelo por la pérdida y a causa de ello, tal vez, el nombre escrito no recobre en su vacío/pleno nunca lo perdido.

Karla Guaquín en el poema "Ñuke mapu puke weychafe", "Guerreros de la madre tierra" (Hilando 2009, 73), construye una voz poética que acoge la llegada de dos muertos: Matías Catrileo y Alex Lemún. El tono de la acogida poética no es fúnebre, el temple es celebratorio: "marrichiweo!!” es el grito que dice "venceremos, diez veces venceremos". Como si la muerte de Catrileo, joven estudiante universitario de 23 años, a manos de la policía de Chile el año 2008 y la de Lemún, estudiante de diecisiete años, en el año 2002, muerto a causa de un perdigón de plomo en la cabeza disparada desde una escopeta Winchester, se volvieran un lugar de resistencia memoriosa inacabable. El poema termina con la repetición cíclica del winka que se esconde, luego de despojar y asesinar a mansalva, en las "normas del poder" colonial-capitalista:

en el mismo año
en el mismo mes
en el mismo día
que sus pasos exudan traición.

Si como afirma Butler, la pérdida nos reúne a todos en un tenue nosotros, esta voz poética convoca esa imagen de lo humano que nos toma de la mano para volver a preguntarnos por las vidas que cuentan como tales y lo que hace que una vida valga la pena (Butler 47).

\section{Cierre en suspenso}

Pienso en la noción de tono poético. La imagino en consonancia con lo que Blanchot refiere respecto del tono en la escritura. Si al escribir damos lugar a lo incesante, aquello que nunca termina, entonces el tono que nos conmueve es aquel que hace silencio en la escritura para dar lugar al eco de lo que no puede dejar de hablar, así toma forma y sentido aquello que habla interminablemente (20-21). De esta manera me atrevo a nombrar el impulso poético de tono memorioso que surge en las escrituras de las mujeres mapuche. He perseguido, en consecuencia, ese pulso, su modulación sinuosa, arrebatada, melancólica o en calma espiritual al leerlas y me he subido a esa 
amplificación haciendo gala de lo que Genovese llama el "arrastre subjetivo" (19) despertado por la escritura poética, ese que estalla como labor creadora de sentidos. Si la cuestión central del ímpetu lírico es "el deseo", como afirma la misma poeta argentina, me siento autorizada para conectar esta aseveración con el bello lema de Ricoeur: "la fidelidad al pasado no es un dato es un deseo" (633). En este singular lenguaje poético mapuche la fidelidad/deseo sería un pliegue múltiple que se halla en cada recodo sinuoso de las palabras en mapudungun y en español, en esa presencia/ ausencia de ambas lenguas, su ambigüedad y su certeza, en su música y en sus sinsentidos reverberantes.

Mujeres mapuches, sujetos deseantes en la escritura poética memoriosa que explosiona y le pone rostro a la carencia, nombre a lo perdido, denuncia al despojo, da luz a lo recobrado, eco a lo imaginado, todo ello como posibilidad de nombrar el triunfo memorioso. En esta labor de reencuentro en la escritura con lo perdido/ arrebatado, algo se revela vinculado con aquello que las poetas devienen, llegan a ser. Judith Butler nos señala que cuando enfrentamos el trabajo de duelo algo de nosotros se nos revela, y ese algo dibuja el lazo que nos une a los otros y a las otras. Lazos o nudos que nos constituyen en la posesión/desposesión. Así la emergencia de lo ético-político posibilita elaborar el sentido de una comunidad: nuestra dependencia y nuestra responsabilidad ética para pensar(nos) (49). Estas mujeres mapuche nos entregan un conjunto múltiple de imaginaciones de lo poético que se hallan ancladas en experiencias de sujetos diversos, complejas y potencialmente contradictorias por el sólo hecho de constituir elaboraciones de mujeres cruzadas por variables sociosimbólicas: género y etnia.

Sí, en ocasiones esta lectura me pone de cara a la negatividad: la fantasmática, un insondable, pero también me enfrento a la afirmación plena regalada por el impulso creador: el recuerdo-imagen abierto y múltiple. Estas escrituras de mujeres mapuche me sitúan ante la interrogación y el desplazamiento del pasado que posibilita habitar transformadoramente el presente y atisbar el futuro en lo pequeño, infinitesimal, abierto siempre a lo im-posible.

Vuelvo mi rostro suspendido hacia la afirmación en la coexistencia de la afectividad e imaginación en trama con el lazo social. Emergencia de una revuelta im-posible que se halla unida a la agonía pendular de las voces poéticas figuradas en la escritura. Vuelvo a las preguntas que me he hecho a lo largo de estas indagaciones de la escritura poética de mujeres mapuche, detonadas por la provocación feminista kristevana: ¿es que las mujeres estaríamos más dispuestas a la revuelta? ¿Las mujeres podríamos re-elaborar un cultivo para la revuelta íntima y la revuelta del lazo social? ¿Cuáles mujeres, situadas en qué territorios? (Luongo 189-190). Si el territorio mapuche, en toda su amplitud, enmarca la producción de estas poetas ¿Cómo pensar la violencia colonial que subyace a la pérdida, como experiencia límite en ese peor orden posible? Como respuesta tentativa afirmo ese margen de resistencia, potencia, rebelión, goce y fiesta de lo poético justiciero que emerge de 
las creaciones de las poetas estudiadas. Goce y fiesta del ejercicio memorioso que re-inventa, así como posibilita la proliferación de diferencias diferentes, la mixtura, las ambigüedades, incertidumbres, los nudos, las salpicaduras (Mora Curriao 335336) en estas creaciones del no olvido de la cultura-escritura mapuche, la que celebra en toda su plenitud la vida/existencia/ experiencia ética-estética y política de las mujeres creadoras mapuche.

\section{Bibliografía}

Antileo, Enrique. “Migraciòn Mapuche y continuidad colonial”. En TA IÑ FIJKE XIPA RAKIZUAMELUWÜN. Historia, colonialismo y resistencia desde el país mapuche. Temuco: Ediciones Comunidad de Historia Mapuche, 2012. Medio impreso. Anzaldúa, Borderlands/La frontera. The new mestiza. San Francisco: Aunt Lute Books, 2007. Medio impreso.

Bello, Álvaro, Etnicidad y ciudadanía en América Latina. La acción colectiva de los pueblos indígenas. Santiago de Chile: Naciones Unidas, CEPAL, Sociedad Alemana de cooperación técnica GTZ, 2004. Medio impreso.

Bengoa, José. Historia del pueblo mapuche. Siglos XIX y XX. Santiago de Chile: LOM, 2008. Medio impreso.

Blanchot, Maurice. El espacio literario. Barcelona: Paidós, 1992. Medio impreso.

Braidotti, Rosi. Transposiciones. Sobre la ética nómada. Barcelona: Gedisa, 2009. Medio impreso.

Butler, Judith. Vida precaria. El poder del duelo y la violencia. Buenos Aires: Paidós, 2009. Medio impreso.

Falabella, Soledad, Ramay Allison, Huinao, Graciela (eds.). Hilando en la memoria. 7 mujeres mapuche. Santiago de Chile: Cuarto Propio, 2006. Medio impreso.

Falabella, Soledad, Huinao, Graciela, Miranda Rupailaf, Roxana (eds.) Hilando en la memoria. Eрu rupa. 14 mujeres mapuche. Santiago de Chile: Cuarto Propio, 2009. Medio impreso.

Foucault, Michel. ¿Qué es un autor? Buenos Aires: Ediciones Literales, 2010. Medio impreso.

Genovese, Leer poesía. Lo leve, lo grave, lo opaco. Buenos Aires: Fondo de Cultura Económica, 2011. Medio impreso.

Kristeva, Julia. La revuelta íntima. Literatura y psicoanálisis. Buenos Aires: Eudeba, 2001. Medio impreso.

Luongo, Gilda. "Memoria y revuelta en poetas mujeres mapuche: intimidad/lazo social I". En Aisthesis No 51 (2012): 185-201. Medio impreso.

Luongo, Gilda. "Writing, memory and rebellion in mapuche women poets." Conferencia leída en el marco de "The Latin American Studies-Symposium. The recovery of memory. Studies in the discourse of women's poetry in Latin america's 
Southern Cone”. Evento que se llevó a cabo en Universidad de Essex, Inglaterra, el día martes 18 de junio del año 2013. Escrito sin publicar.

Mora Curriao, Maribel y Moraga, Fernanda (eds). Kümedungun/Kümewirin. Antología poética de mujeres mapuche (siglos XX-XXI). Caniguán, Jacqueline (versión mapudungun). Santiago de Chile: LOM, 2010. Medio impreso.

Mora Curriao, Maribel. "Poesía Mapuche del siglo XX: Escribir desde los márgenes del Campo Literario”. En Nahuelpan Moreno, Héctor, Huinca Piutrin, Herson, Marimán Quemenado, Pablo, Cárcamo-Huechante, Luis, Mora Curriao, Maribel, Quidel Lincoleo, José, Antileo Baeza, Enrique, Curivil Bravo, Felipe, Huenul Colicoy, Susana, Millalen Paillal, José, Calfío Montalva. Margarita, Pinchinao Huenchuleo, Jimena, Paillan Coñoepan, Elías, Cuyul Soto, Andrés. TA IÑ FIJKE XIPA RAKIZUAMELUWÜN. Historia, colonialismo y resistencia desde el país mapuche. Temuco: Ediciones Comunidad de Historia Mapuche, 2012. Medio impreso.

Nahuelpán, Héctor. “Formación colonial del Estado y desposesión en Ngulumapu”. En TA IÑ FIJKE XIPA RAKIZUAMELUWÜN. Historia, colonialismo y resistencia desde el país mapuche. Temuco: Ediciones Comunidad de Historia Mapuche, 2012. Medio impreso.

Ricoeur, Paul. La memoria, la historia, el olvido. Buenos Aires: Fondo de Cultura Económica, 2010. Medio impreso.

Sierra, Marta. "Presentación” en Bernardita Llanos y Ana María Goetschel (eds.) Fronteras de la memoria. Cartografías de género en artes visuales, cine y literatura en las Américas y España, Santiago de Chile: Cuarto Propio/Ecuador: Flacso, 2012. Medio impreso.

Recibido: 13 marzo 2014

Aceptado: 30 abril 2014 